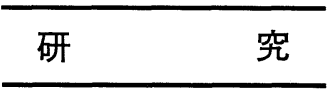 \\ 声帯の粘膜波状運動について \\ $\begin{array}{llr}\text { 黒川 } & \text { 浩伸・岡本 } & \text { 和憲 } \\ \text { 湯本 } & \text { 英二・丘村 熙 }\end{array}$
}

\section{Traveling Wave in Vocal Fold Vibration}

\author{
Hironobu Kurokawa, Kazunori Okamoto, \\ Eiji Yumoto and Hiroshi Okamura \\ (Ehime University)
}

The authors reviewed the literature on the mode of vocal fold vibration, which has been considered to be a transmission of the mucosal wave upward from the lower surface of the vocal fold. Many high-speed cinematographic or stroboscopic images have been obtained from the supraglottic area, but the vibratory mode of the lower surface of the vocal fold remains unclear. We observed vocal fold vibrations from the infraglottic as well as the supraglottic areas with high-speed cinematography and found that:

1) Traveling waves moved upward from the mucosal upheaval or inside it. That is, the mucosal upheaval vibrated with an earlier phase than any other portion of the vocal fold.

2) In the closing phase, the lower lip became a free edge and moved upward. After contract of the lower lips of both sides in the midline, lower lip became the upper lip and moved upward. At the time of contact, the reflection wave, identified as the lower lip from the infraglottic image, retracted laterally rapidly.

3) At the end of the opening phase, the lower lip of the next cycle began to move medially.

4) The mucous membrane outside of the mucosal upheaval did not virbrate actively.

5) On the basis of these findings, we tried to diagram the frontal sections of the vibrating vocal fold in different phases.

Key words: traveling wave, lower lip, upper lip, mucosal upheaval, high-speed cinematography

はじめに

声帯振動に関する研究は高速度映画, スト口 ボスコピー，X線ストロボスコピー等を用いて 数多く行われてきた.しかし，多くの研究は声
帯上面からの観察であり，声帯下面から観察し た声帯振動, とくにヒダ状粘膜隆起・粘膜の波 頭の動きに関しての詳細な報告は数少ない。ま た従来の説明では, 発声時声帯粘膜にみられる 
波状運動に際して生じる粘膜の波頭である上唇 と下唇が，それぞれ独立して開閉運動を行って いるかのような印象を与えやすい.

そこで，著者らはまず現在までに行われてき た研究について文献的に考察して声带振動様式 に関する現在までの知見を整理した。ささらに犬 摘出喉頭の吹鳴を行い，高速度映画を用いて振 動中の声帯下面を観察し, ヒダ状粘膜隆起, 粘 膜の波頭の上面からでは観察できない詳細な動 きを検討した。

\section{文献的考察}

1937年 Bell Telephone Laboratories におい て，人発声中の声帯振動を初めて高速度映画撮 影に成功して以来, 声帯振動の研究は格段の進 歩を遂げた. それ以後, 高速度映画 ${ }^{1)}$ (14)・スト口 ボスコピー15) 18)・X線ストロボスコピー19) 22) などを用いて数々の研究が報告された。 以下に 会話音域中の声帯振動について主な研究結果を 紹介し，現在なお十分に解明されていない問題 点を挙げた.

Farnsworth $^{1)}$ は Bell Telephone Laboratories のフィルムを観察し，「低い周波数で振動中の 声帯は声帯下面から上方に向かって開いていく. また下部は最初に閉鎖し始める。すなわち，上 下の 2 点間に招いて位相差を認める」と分析し た. Timcke ${ }^{2)}$ は人発声時の声帯振動を高速度 映画で撮影し「上唇の振幅の方が下唇のそれよ りあ大きく，位相に関しては下唇の方が早い」 と述べた. 吉田 ${ }^{9)}$ は同じく人発声時の声帯振動 を高速度映画で撮影し「声帯全体としての内下 方と外上方の間を往復する声門開閉運動に，粘 膜の波状運動が組合わさったもの」と声帯振動 を観察し，乙の結果は広戸の提唱した mucoviscoelastic-aerodynamic theory ${ }^{7)}$ に一致すると 述べた．平野 ${ }^{102}{ }^{23)}$ は人声帯の層構造を組織学的 に検討し，声帯は cover（上皮および固有層浅 層）と body（声帯筋および固有層中間層・深 層）加ら成る振動体である，之いう body-cover theoryを提唱した。ささらに平野は声帯の振動に cover が大きく関与していると述べた.
松下 ${ }^{8)}$ は人および犬摘出喉頭を用いて初めて 声帯下面㧍よび側面より声帯振動を高速度映画 で撮影した。「声帯下面と声門下腔との境界部 にヒダ状粘膜隆起が形成される. 声帯が主とし て振動するのはこの隆起より上内方の部分であ り，粘膜波状運動はこの隆起の少し上方から始 まり上部へと伝播する。すなわち声帯辺縁の上 部之下部との運動には位相差が認められる。ま たこの隆起より下外方の声門下腔粘膜はほとん ぞ振動しない」と述へ，「声帯振動は声帯辺縁 粘膜の波状運動にほかならない」と結論づけた. Baer ${ }^{18)}$ は犬摘出喉頭に打いて，炭素の小片を声 帯表面につけ上面执よび下面からストロボスコ ピーで観察した。 その結果, 下方より上方へ進 む声帯の表面波が声帯振動に大きく関与してい るとし，body-cover theoryを支持した.

斉藤 ${ }^{199}$ はX線ストロボスコピーを開発するこ とにより前額面からの観察を可能にした. 犬摘 出喉頭の観察より「下唇と思われる場所よりも 下方に扔いて隆起が現れ，規則的な振動を行っ ているように見える。乙れはより早く閉鎖し， より早く開大する」と述べた。磯貝 ${ }^{200}$ はX線ス トロボスコピーを用い，鉛の小片を犬声帯粘膜 層内に刺入して観察し「声帯を構成する各点は, 垂直成分・水平成分の両成分に沶いて，位相・ 振幅を少しずつずらした運動をする」と述べ, 松下の報告之同様に「声帯振動の本質は粘膜の 波状運動である」と結論づけた。また，都築 は犬の声帯筋層内に鉛の小片を刺入してX線ス トロボスコピーにて声帯振動を観察し「声帯筋 層は音源振動体として参加していない」と述べ た.

現在のところ, 声帯振動は声帯の下面に粘膜 の隆起（波頭）が生じ, この隆起が下方より上 方へと伝播する，すなわち粘膜の波状運動であ ると考えられている. body は声帯振動におい て一定の役割を演じているものの，音源振動 体としての主役は cover である粘膜とされてい る20) 22) 23).

一方，振動中の声帯下面の観察は容易でなく， 
人または犬の摘出喉頭を用いてわずかに報告さ れたのみで8) 12) 14) 18)，粘膜波動の発生する部位・ 時期とその動き，ヒダ状粘膜隆起の動きとその 形成される位置, さらにヒダ状粘膜隆起亡声帯 の他の部位との位相差などについてなお不明確 な点を残したままである。

そこで，著者らは犬摘出喉頭を用いて吹鳴実 験を行い，波状運動に際して生じる粘膜の波頭 とヒダ状粘膜隆起の動きを分析してきたので， その概要を報告する．また，乙の結果に基づい て振動声帯の前額断面図を描いてみた。

\section{実験方法}

実験には 3 個の成犬摘出喉頭を用いた。声帯 上面を観察しやすくするため，仮声帯より上部 を切除した。気管側は輪状軟骨と第一気管輪と の間で切除した. 高速度カメラを用いて振動時 の粘膜表面の 1 点の動きを波頭之関連づけて検 討したものは声帯上面から観察したものがある にすぎない1113)。また鉛片を用いてX線ストロ ボスコピーにより粘膜固有層・筋層の動きを観 察した報告もあるが(2) 19) 20) 22)，微細な粘膜の波 状運動に鉛片の插入が影響を与える可能性があ る. 以上の理由から著者らは 3 個の摘出喉頭の

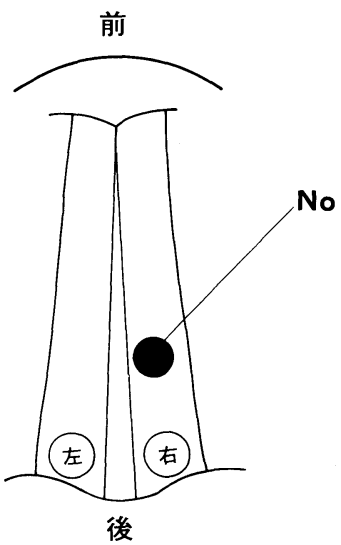

声帯上面

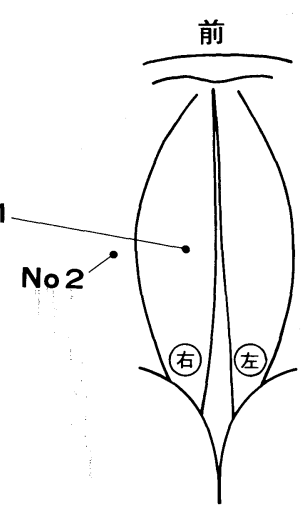

後
声帯下面

図 1 マークの位置

No 1 には右側声帯上面やや後方と右側下面中央 部に，No 2 には右側声帯中央部でヒダ状粘膜隆 起が形成される位置よりさらに下方にマークした.
声帯上面及び下面に，分析の際の標識として 27 G 針を用いてピオクタニンあるいは墨汁でマー クした. No 1 の犬には右側声帯上面やや後方 に，また右側下面中央部で遊離縁よりほんの少 し下方にマークした. No 2 には右側下面中央 部でヒダ状粘膜隆起が形成される位置よりさら に下方と考えられる位置にマークした(図 1 ).

No 3 にはマークをしなかった。

吹鳴に必要な声門閉鎖を得るために両側声帯 軟骨部を 4-0 ナイロン糸で縫合した. 声帯上面 を外に向けてガラス箱に開けた小孔に喉頭を固 定し，ガラス箱の側面よりビニールチューブを 介して加湿した空気を送気した。喉頭を吹鳴さ せ上面は直接，下面はガラス箱越しに秒速 4000 コマで高速度映画（日立 Hymac）に撮影した (図 2). 声帯振動を観察したフィルムは 1 コマ ごとに film motion analyzer (Nac 社 MC-08) を用いて解析した。吹鳴音はテープに録音しピ ッチを測定した.

\section{実験結果}

1. 声帯上面の観察

犬 No 1 の右声帯上面やや後方のマーク点沶 よび遊離縁の軌跡を図 3 亿示す．マークを大き くつけ，マークの内側・外側の 2 点を分析した. ピッチは $479 \mathrm{~Hz}$ であった。

閉小期に波頭が下方より上内方へと進み，対 側の波頭と衝突した．衝突後，波頭は対側のそ

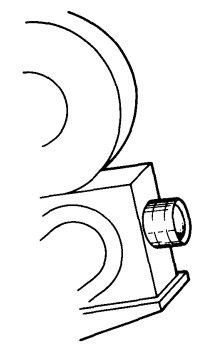

高速度カメラ

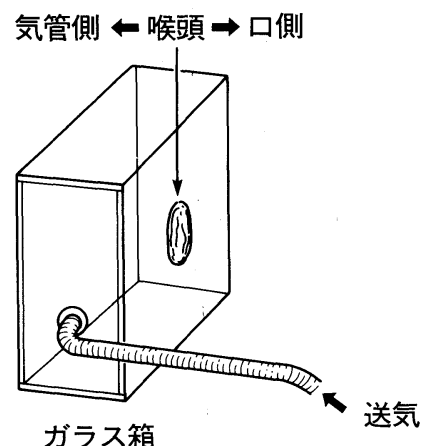

図 2 実験装置
ガラス箱に開けた小孔に摘出喉頭を固定し, 上面は直 接，下面はガラス箱越しに高速度カメラで撮影した。 
れと共に上方へ移動した．次いで減衰しながら 外方へ向かい，やがて消失した。

マークの内側は開大期には遊離縁より下方に 位置し上方からは観察できなかった。閉小期に はいるとマーク内側が見え始め，遊離縁が合し てしばらくすると再び観察できなくなった。、 ーク外側の点は振幅が小さく, 内側の点に比べ ると約 30 度位相の遅れを認めた。マークの外側 と内側の二点間の距離は閉小期に徐々に長くな った。

右 側
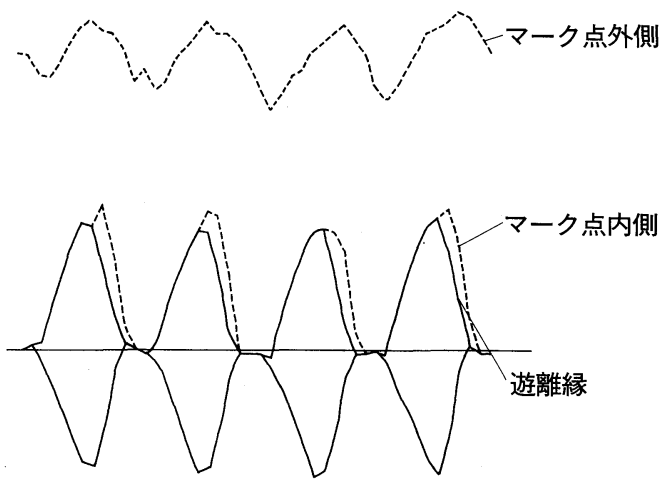

左 側

図 3 犬 No 1 上面の軌跡

正中線より上が右側，下が左側を示す．上の破線 よりマーク点外側縁, 同内側縁, 遊離縁右側, 同 左側を示す.

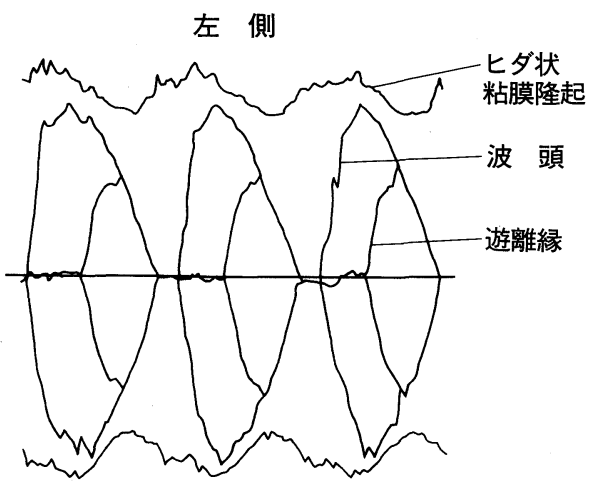

右 側

図 4 犬 No 3 下面の軌跡

正中線より上が左側，下が右側を示す. 図 5 , 6 亿ついても同様. 正中より遊離縁，波頭， ヒダ状粘膜隆起の軌跡を示す.

\section{2. 声帯下面の観察}

1 ）声帯膜様部中央の分析

犬 No 3 の声帯膜様部中央における遊離縁, 粘膜波頭沶よびヒダ状粘膜隆起の軌跡を図 4 亿 示す.ピッチは $208 \mathrm{~Hz}$ であった.

ヒダ状粘膜隆起部に生じた波頭は上内方へ進 んで遊離縁となり閉小期が開始した。やがて対 側の波頭と正中で衝突し，合したまま上方へ移 動した．衝突した際に下外方へ速やかに移動す るやや小さい波頭が認められ，ヒダ状粘膜隆起 部に達して消失した。この波頭は衝突に際して 生じる反射波と考えられた。その後左右の遊離 縁が離開を始める頃に次の周期の波頭が観察さ れた（後述のように犬 No 1 では, 左右の遊離 縁が離開してしばらくしてから次の周期の波頭 が観察された)。遊離縁より少し下方に前連合 部より披裂軟骨声帯突起にかけて生じたヒダ状 粘膜隆起は，振幅は小さいが遊離縁の開大・狭 小に伴い振動した。 ヒダ状粘膜隆起より下外方 の粘膜には波状運動は認められなかった。

次に犬 No 1 の下面右声帯膜様部ほぼ中央の マーク点，遊離縁，粘膜波頭の軌跡を図 5 亿示 す。なお七ダ状粘膜隆起の軌跡は一部不明確な 部分があったため記載しなかった。

マークはヒダ状粘膜隆起が観察される位置よ

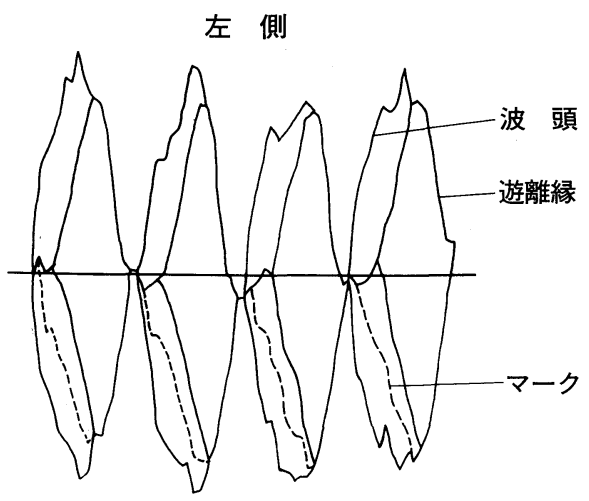

右 側

図 5 犬 No1 下面マーク点の軌跡 破線がマーク点の軌跡を示す．他の線は正中 より遊離縁と波頭の軌跡を示す。 
り内側に認められた。マークは波頭がヒダ状粘 膜隆起部より内方移動を開始するとしばらくし て観察できなくなった。波頭が正中で衝突した 後，下外方へ移動する波頭，すなわち反射波が 認められるようになるとマークは見え始めた.

その後マークと反射波の距離は徐々に長くなり， やがて再び徐々に短くなった後，観察できなく なった，位相に関してはマーク点はヒダ状粘膜 隆起より遅かった.

最後に犬 No 2 におけるマーク（ヒダ状粘膜 隆起より外側)，遊離縁，ヒダ状粘膜隆起の軌跡 を図 6 亿示す。な拈膜波頭の軌跡は一部分が 不明確なため記載しなかった。ピッチは $288 \mathrm{~Hz}$ であった。

マーク点の振幅はヒダ状粘膜隆起のそれより 小さく, 動きは七ダ状粘膜隆起の動きに比して 若干の位相の遅れを認めた。このととからマー ク点の振動はヒダ状粘膜隆起に生じた振動の一 部が下外方へ伝播した結果に過ぎないと考えら れた。

\section{考察}

声帯振動を声帯の上面および下面から観察し， 粘膜の波頭, ヒダ状粘膜隆起等の動きについて 分析した。また声帯粘膜表面につけた標識点の

左 側

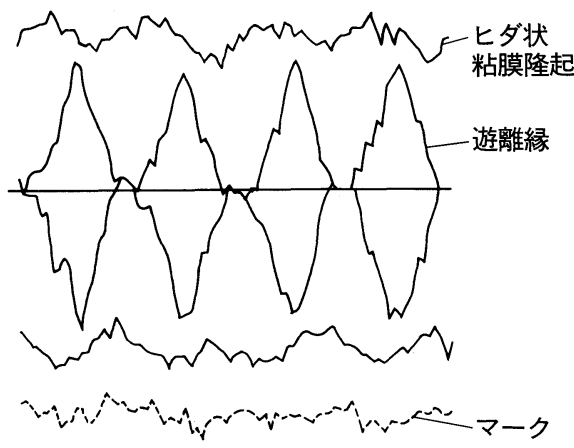

右 側

図6 犬 No2 下面マーク点の軌跡 破線がマーク点の軌跡を示す. 他の線は正中 より遊離縁とヒダ状粘膜隆起の軌跡を示す.
分析を併せて行い，X線ストロボスコピーによ る前額断面の声帯振動の観察 ${ }^{19}$ 20) を参考にして 声帯粘膜の垂直方向の動きを推定し，前額断面 図を描いた (後述).

声帯上面マークの動き(図 7)：犬 No 1 上面 のマークの内側（\#4）は閉鎖期より開大期に かけて観察できない，開大期にはマークの内側 は遊離縁よりも下方に移動するからである．閉 小期には波頭（\#1'）が遊離縁となり，内上方 へ進むためマーク内側が観察できるようになる。 切替 ${ }^{15)}$ は炭末を標識として人の声帯振動をスト ロボスコピーにて観察した際に同様の所見を認 め，その原因は声带辺縁粘膜が開大期に内下方 へ捲れ込むように移動するためであり，上方へ 捲れ上がる運動はしないと述べた．吉田 ${ }^{9)}$ は声 門が開き始める際に辺縁部はかえって内側方に 捲れ込まれて下方に下がるように見える場合が

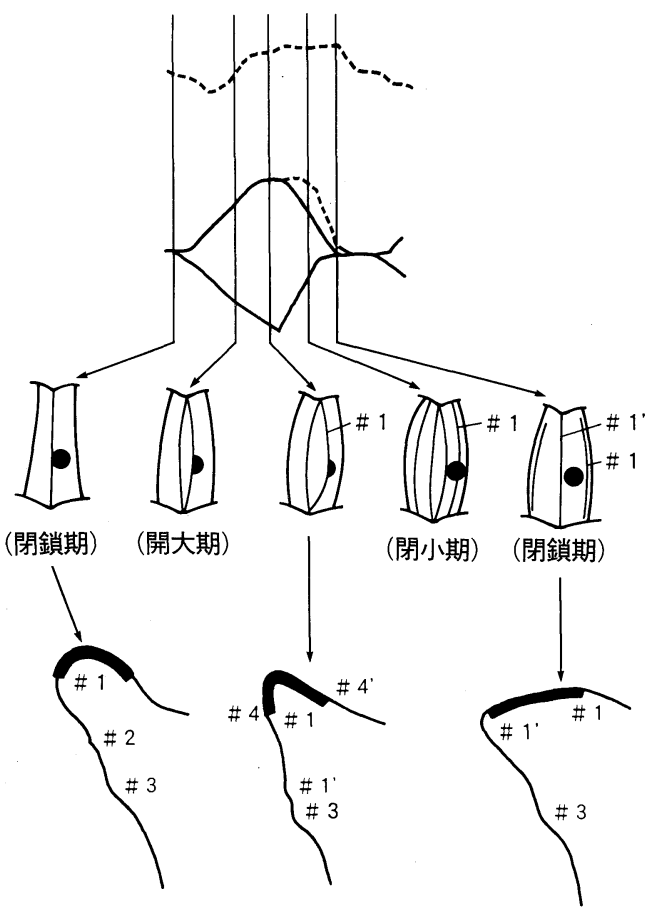

図 7 犬 No 1 上面の軌跡図, 声帯上面模式図 および前額断面図
\#1: 波頭
\#1'：次の周期の波頭
\#2:反射波 \$3: 七ダ状粘膜隆起
\$4: マーク内側縁 \#4': マーク外側縁 
生じると観察した。乙れは波頭が上部に盛り上 がり，斬時との波頭による盛り上がりが外側に 移動するからであるとした。 また平野 ${ }^{11}$ は人声 帯上面の粘膜表面の異なる部位の血管を標識と して，高速度カメラで振動中の声帯を観察した。 声帯上面の内側と外側の血管の 2 点間の距離が 振動中に変化し，乙れは声帯上面の形態が変化 するからであると，今回の実験と同様の結果を 述べている.

声帯下面マークの動き(図 8)：犬 No1 の下 面にマークした点（\# 4 : ヒダ状粘膜隆起より内 側に位置）は閉鎖期より開大期にかけて観察で きる. 閉鎖期に 波頭（\#1）は上方へ移動し， 波頭よりもマークが下外方に位置するからであ る. 開大期においては波頭は外方へ移動するが， マークは遊離縁（\#5）より下方に位置するため

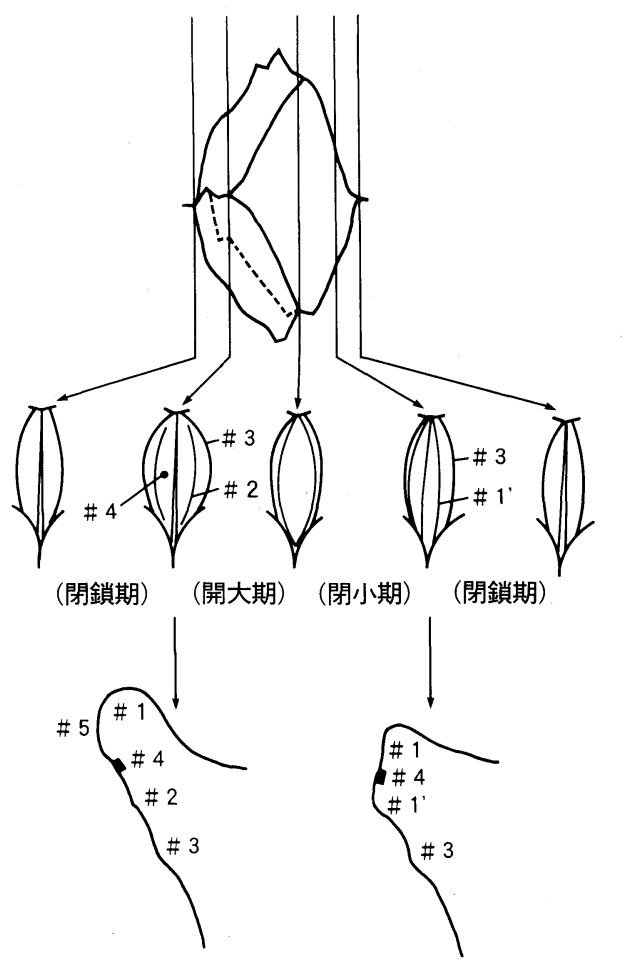

図 8 犬 No 1 下面の軌跡図, 声帯下面模式 図求よび前額断面図
$\# 1$ : 波頭
\#1' : 次の周期の波頭
\#2: 反射波
\#3：ヒダ状粘膜隆起
\#: マ:ーク
\#5:遊離緑

観察される。しかし，閉小期には波頭(\#1') が 上内方へと移動し波頭よりマークが上外方に位 置するようになるから観察できない.

従来報告されてきた声帯振動の前額断面模式 図(図 9 ${ }^{1022425)}$ は, 声帯縁に 2 つの隆起, す なわち上唇と下唇が存在し, 開大期に外側に移 動した上唇が，本来であれば閉小期に減衰しな がら外側に移動するのに，内側に移動し対側の 上唇と合するような印象を与える。 そてで著者 らの研究結果に基づいて一周期の声帯振動の前 額断面図を図10に描いた。図10 a ，b，c は閉 鎖期を示す。図10 a は両側の波頭（\#1）が正中 で衝突した相で, 下方の隆起はヒダ状粘膜隆起 （\#3）である. 図10bは正中で衝突した両側の 波頭が合したまま上方へ押し上げられた相で， 波頭の少し下方の小隆起は反射波（\#2）を示す.

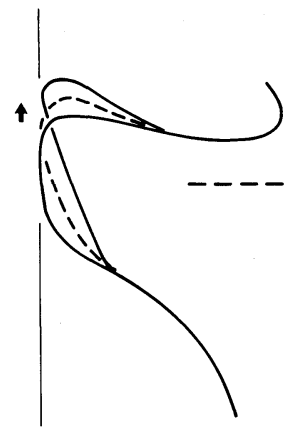

a. 閉鎖期

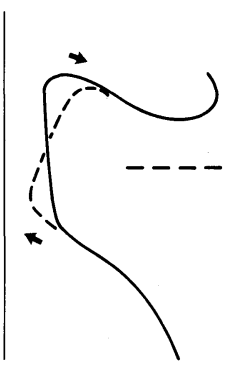

c. 最大開大期

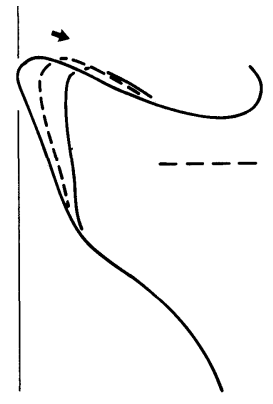

b. 開大期

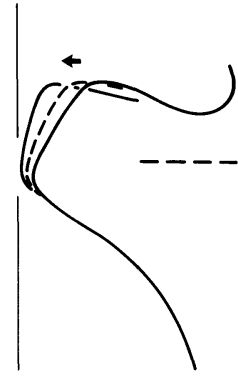

d. 閉小期
（垣田有紀，他：1976 $6^{25}$ より転載）

図 9 垣田 ${ }^{257}$ にるる前額断面図
a . 閉鎖期
b. 開大期
c . 最大開大期
d. 閉小期 
図10 c は閉鎖期より開大期への移行の相で，反 射波はヒダ状粘膜隆起部に達して消失している. 図10 d は開大期を示す。波頭（\#1）は外方へ減 衰しながら移動し，七ダ状粘膜隆起の少し上方 に次の周期の波頭（\#1'）が出現している相で ある. 図 $10 \mathrm{e}$ は閉小期を示す．次の周期の波頭 が内上方へ移動している相である。また前周期 の波頭はさらに外側に移動している.

ヒダ状粘膜隆起と，この隆起より上方・下方 のマーク点の分析結果から七ダ状粘膜隆起の位 相が最も早いととがわかる．斉藤 ${ }^{199}$ が報告した 「より早く閉鎖し，より早く開大しようとする 下唇より下方の隆起」は，七ダ状粘膜隆起飞相 当すると考えられた。

以上，声帯下面からの観察を中心に声帯振動 の際に生じる現象，すなわち粘膜の波状運動に ついて犬摘出喉頭を用いて検討したので報告し た。今後, さらに分析点, ピッチや強さを変化 させ，七ダ状粘膜隆起や波頭の動きを分析した いと考えている。

$$
\text { まとめ }
$$

犬摘出喉頭において，声帯上面および下面を ピオクタニンあるいは墨汁でマークして，高速 度映画を用いて声带振動を観察した。

1）波状運動はヒダ状粘膜隆起あるいはこれ よりほんの少し内側から起こり上方へ進んだ. 従って, 振動声帯においてヒダ状粘膜隆起の振 動は他のよ゙の部分よりも位相が早かった.

2) 粘膜の波頭は正中で衝突した後，対側の 波頭と合して上方へ進んだ。衝突した際，その 反射に相当する下外方へ進む粘膜の波頭が生じ た。

3）遊離縁が外方移動を開始した直後，もし くはしばらくして次の周期の波頭が七ダ状粘膜 隆起部に生じた。

4）七ダ状粘膜隆起より下外方の粘膜にみら れた振動は，七ダ状粘膜隆起に生じた振動の一 部が下外方へ伝播した結果に過ぎないと考えら れた.

5 ）今回の実験結果に基づいて，振動声帯の より正確な前額断面図を描いた。

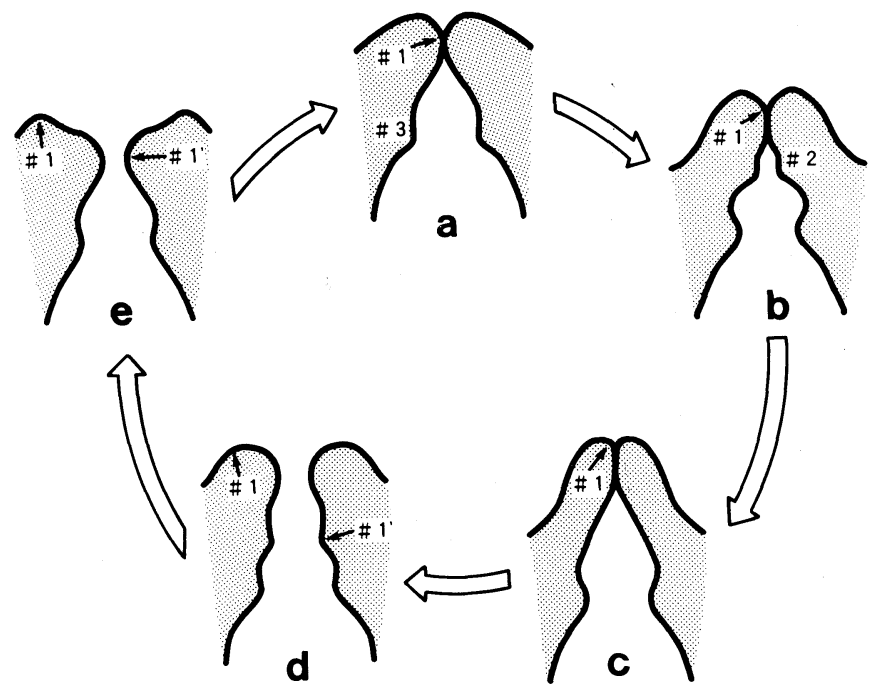

図10 著者らの前額断面図
a , b , c : 閉銷期
$\mathrm{d}$ ：開大期
\#1:波頭
\#1'：次の周期の波頭
籼：反射波
\#3: ヒダ状粘膜隆起

e : 閉小期 


\section{参考文献}

1) Farnsworth DW : High-speed motion pictures of the human vocal cords. Bell Laboratories Record $18:$ 203 208, 1940.

2) Timcke $\mathrm{R}$, von Leden $\mathrm{H}$ and Moore GP : Laryngeal vibration; measurements of the glottic wave part I ; the normal vibratory cycle. Arch Otolaryngol $68: 1 \sim 19,1958$.

3 ) Rubin HJ and Cover LEM : Technique of highspeed photography of the larynx. Ann Otol Rhinol Laryngol $69: 1072 \sim 1082,1960$.

4) von Leden $\mathrm{H}:$ The mechanism of phonation. Arch Otolaryngol $74: 72 \sim 83,1961$.

5 ) Moore GP, White FD and von Leden H : Ultrahigh speed photography in laryngeal physiology. J Speech Hear Res $27:$ 165 171, 1962.

6 ）広戸幾一郎, 吉田義一, 中山 亨 : 声帯振動の高 速度映画撮影について。耳鼻臨床 $59: 47 \sim 55$, 1966.

7 ）広戸幾一郎 : 発声機構の面よりみた喉頭の病態生 理. 耳鼻臨床 $39: 229 \sim 291,1966$.

$8 ）$ 松下英明：高速度映画による摘出喉頭における声 帯振動に関する実験的研究. 耳鼻 $15: 127 \sim 142$, 1969.

9 ）吉田義一：高速度映画による発声時の声帯振動に 関する研究. 日耳鼻 $72 ： 1232 １ 256 ， 1969$.

10）平野 実：音声外科の基礎と臨床. 耳鼻 $21: 239$ $\sim 442,1975$.

11) Hirano M, Kakita $Y$, Kawasaki $H$, et al : Data from high-speed motion picture studies. Vocal fold physiology (ed by Stevens $\mathrm{KN}$ and Hirano M). pp 85 93, University of Tokyo Press, Tokyo, 1981.

12) Fukuda H, Saito S, Isogai $Y$, et al : Vocal fold vibration in excised larynges viewed with an $\mathrm{X}$ ray stroboscope and ultra-high-speed camera. Vocal fold physiology contemporary research \& clinical issues (ed by Bless DM and Abbs $\mathrm{JH}$ ). pp 238 252, College Hill Press, San Diego, 1983.
13）松尾浩一：声帯前後軸の層構造を考慮した振動の 分析. 耳鼻 $29: 149 \sim 161,1983$.

14）湯本英二：音声外科の立場加ら一声带への手術侵 襲と術後の声帯振動. 音声言語医学 $29 ： 203 \sim$ 207, 1987.

15）切替一郎：喉頭ストロボ活動写真撮影法による発 声時における人間声帯の振動ならびに声門開閉の 時間的関係に関する研究. 日耳鼻 $49: 236 \sim 262$, 1943.

16) Smith $S:$ Remarks on the physiology of the vibrations of vocal cords. Folia Phoniat $6: 166 \sim 178$, 1954.

17）古川 満 : 摘出喉頭による発声機構に関する研究. 耳鼻臨床 $60 ： 145 \sim 181,1967$.

18) Baer $\mathrm{T}$ : Observation of the vocal fold vibration ; measurement of excised larynges. Vocal fold physiology (ed by Stevens KN and Hirano $\mathbf{M}$ ). pp119 133, University of Tokyo Press, Tokyo, 1981.

19）斉藤成司 : 発声機構の基礎的研究および喉頭内腔 への臨床的アプローチ. 耳鼻 $23: 177 \sim 189,1977$.

20）磯貝 豊：X線ストロボスコピーによる声帯振動 の解析. 耳鼻 $27: 883 \sim 930,1981$.

21）都築 達 : 声帯層構造を考慮した声帯振動の基礎 的研究. 耳鼻 $30: 131 \sim 152,1984$.

22）川崎順久：多面的観察による声帯振動の基礎的研 究. 日気食会報 $39: 476 \sim 492 ， 1988$.

23）平野 実: 振動体としての声帯の構造. 日耳鼻 $76: 1341 \sim 1349,1973$.

24）平野 実：声帯振動の基本的パターン。日耳鼻 $77:$ 108 111, 1974 .

25）垣田有紀，平野 実，川崎 洋，他：声帯の層構 造を考慮した振動状態の模式的表示一正常声帯の 場合一. 日耳鼻 $79: 1333 \sim 1340 ， 1976$.

$\left(\begin{array}{l}\text { 原稿受付 : 平成元年 } 12 \text { 月 } 4 \text { 日 } \\ \text { 原稿採択 : 平成 } 2 \text { 年 } 6 \text { 月 } 15 \text { 日 } \\ \text { 別刷請求先 : 黒川浩伸 } \\ \text { ⿳ } 791-02 \text { 愛媛県温泉郡重信町志津川 } \\ \text { 愛媛大学医学部耳鼻咽喉科学教室 }\end{array}\right)$

